\title{
A Monopoly Model Of Accounting Fraud
}

\author{
Laura Ebert, (E-mail: Laura.Ebert@Marist.edu), Marist College \\ Margaret L. Gagne, (E-mail: Margaret.Gagne@Marist.edu), Marist College
}

\begin{abstract}
A monopoly model is used to show why a CEO would engage in accounting fraud, high risk behavior given the severe negative consequences, should the fraud be exposed. A monopoly model of the market transaction between the buyer of the fraud, the CEO, and the seller of the fraud, the accountant, demonstrates the motivation behind the CEO's willingness to engage in the fraud. The accountant (seller) receives a monopolist profits while the CEO (the buyer) pays a price equal to the perceived net marginal benefit. The CEO wants the accountant to believe that the net marginal benefit equals the price when in fact the actual net marginal benefit to the CEO is much lower than the monopolist's price. The resulting cost to the CEO for fraud is relatively low because of the CEO's ability to shift a substantial portion of the cost to the company.
\end{abstract}

\section{INTRODUCTION}

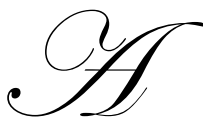

ccounting scandals have consistently made the headlines recently. According to a KPMG report (2003), accounting fraud is the most costly form of financial fraud. The same report estimates that the average cost to the American economy is approximately $\$ 250$ million. In addition, PricewaterhouseCoopers (2003) reports an average loss per company of approximately $\$ 2.2$ million. The problem of accounting fraud is not limited to the United States and in their 2003 report, PricewaterhouseCoopers (PwC) states that economic crime such as accounting fraud is a significant threat worldwide, and most organizations expect it to increase in the next five years. The KPMG report (2003) reaches the same conclusion: the amount of fraud is increasing over time.

A common characteristic of accounting fraud in corporate America, according to the Securities and Exchange Commission, is that fraud investigations tend to involve key corporate executives at the top of the company: "The top executives' positions allow them to override existing internal controls and to influence subordinates to perpetrate the fraud." (Beasley et al. ????). Currently, the Enron accounting fraud trials of Kenneth Lay and Jeffrey Skilling are underway. Kenneth Lay, the founder and chairman of Enron and Jeffrey Skilling, the president, face conspiracy and securities fraud charges brought by the government (Nichols 2005). Each man is facing the possibility of spending much of the rest of his life in jail. Bernie Ebbers, the founder and former CEO of WorldCom, has recently been sentenced to twenty-five years for his part in the accounting scandal dubbed "the largest corporate fraud in history" (Quinn 2005). Scott Sullivan, the chief financial officer of WorldCom, pled guilty to three Securities and Exchange Commission (SEC) violations and struck a deal with federal prosecutors in exchange for building a case against Ebbers (Perilloux 2004). Sullivan and four other executives admitted all charges and turned on Ebbers (Quinn 2005).

This paper focuses on the relationship between the top executive officer of a major corporation and the accountant, the subordinate who is asked to perpetrate the fraud. The payoff to the accountant and benefits that accrue to the CEO are explored. The motivation behind top corporate executives' decisions to engage in accounting fraud given the large penalties if they are caught is examined. This paper demonstrates that it is the ability of the chief executive officer (CEO) of a corporation to extract a rent from the company that increases the motivation to engage in high risk behavior. It is this power of the CEO to extract a rent from the company that explains the relatively large number of top executives in corporate fraud scandals. The model is similar to that presented by Shleifer and Vishny (1993) in that it demonstrates corruption with theft; however, it differs in that marginal cost to the seller of the fraud increases as the quantity of fraud increases. 


\section{PARTICIPANTS IN THE MODEL}

The model provided here is a principal - agent model; the CEO is the principal and the accountant is the agent. In the model presented the CEO has an advantage over the accountant in that (s)he is able to hide the truth about the fraud's true cost to the CEO. The accountant believes what (s)he perceives as the CEO's demand is the true demand curve when in fact it is not. Based on the perceived demand curve, the accountant simply maximizes profits.

In spite of this misperception, the relationship is otherwise close and intimate. The accountant might be the head accountant or chief financial officer (CFO) and have almost equal stature in the company or (s)he might be a relatively low-level accountant. The place of the accountant in the organizational hierarchy matters only in so far as the payoff to the accountant will differ. In either case, the CEO and the accountant have a trusting relationship and the accountant is loyal to the CEO. Whenever the CEO feels the need to "fudge the numbers," (s)he can approach the accountant without fear of reprisal and confidence that his(her) request will be considered and enacted.

Both the CEO and accountant face benefits and costs from accounting fraud. We assume that the accountant has a less expensive lifestyle than the CEO and has less public scrutiny. This would be the case even if the accountant received a very high salary. The CEO, however, is often paid a salary viewed as exorbitant by the public. The CEO's money, power and influence can support a flamboyant lifestyle. His/her reputation and public image are important to the CEO and their potential loss is an important risk of engaging in accounting fraud.

The CEO derives a number of benefits from the fraud; however, the expected benefits are not solely for personal gain. Benefits of fraud to the CEO include financial and professional perks. The company benefits, at least in the short-term, from higher stock prices, increased profits, improved reputation, and greater access to the capital markets.

The benefit of engaging in accounting fraud for the accountant is primarily financial. The accountant may receive cash from the CEO, a pay raise, and/or a promotion. Sometimes, the accountant perpetrates the fraud to keep his/her job. Most likely, the accountant will also own shares of stock and would participate, as any other shareholder, from the increase in the value of the stock if the fraud has such an effect. An additional benefit of engaging in accounting fraud for the accountant is that such activity creates a tighter bond with the CEO, which may provide a future advantage.

When compared with the accountant, however, the CEO has more to lose if caught engaging in fraudulent behavior. Both face similar costs including job loss, income loss, jail time and damage to their reputations among friends and family. The CEO, however, faces another cost, a decline in his/her reputation as a public figure. If caught, the CEO incurs significant damage to his/her public image which can lead to great personal loss.

In the model below, the marginal costs of fraud to both the accountant and CEO change as the level of fraud changes. Marginal cost (MC) to the accountant increases as the quantity of fraud increases; the marginal cost curve is upward sloping. The more fraud committed, the greater the cost of maintaining secrecy about the crime. The more the accountant "fudges the numbers," the greater the likelihood of getting caught. This is different from the government official in the corruption scandal of Shleifer and Vishny (1993) whose marginal cost remained constant no matter what level of fraud was undertaken.

The demand curve or net marginal benefit curve for the CEO is the standard downward sloping demand curve facing a pure monopolist. The CEO's demand curve is downward sloping because, as in the case of the accountant, (s)he faces the rising marginal cost of maintaining the secrecy of the crime. In addition we assume the CEO has diminishing marginal benefits (MB) from the fraud. 


\section{THE MODEL}

In a monopoly, the equilibrium price is determined by the profit maximizing rule where marginal revenue equals marginal cost. ${ }^{1}$ The accountant provides the quantity of fraud where MR $=$ MC and charges a price the market is willing to pay, given that quantity. The monopolist restricts the quantity and then charges the maximum price possible. Price is determined by the market demand curve; in Graph 1, the demand curve is labeled NMB.

The market demand curve represents the CEO's demand for fraud. It is the net marginal benefit (NMB) that accrues to the CEO from the accounting fraud. Net marginal benefit is the difference between the marginal benefit and the marginal cost to the $\mathrm{CEO}(\mathrm{NMB}=\mathrm{MB}-\mathrm{MC})$. An increase in the quantity of fraud leads to a decline in the $\mathrm{NMB}$ due to the rising cost of secrecy. In addition, the CEO faces diminishing returns in marginal utility from the fraud. The MR curve lies below the NMB curve because the monopolist accountant has to lower the price to sell an additional unit of fraud. This means that the change in revenue from selling an additional unit of fraud, the marginal revenue (MR), will fall at a faster rate than the decline in net marginal benefit. This explains why the MR curve in Graph 1 lies below the demand curve. The accountant will set output where MR $=\mathrm{MC}$ and will charge the price, $\mathrm{P}^{*}$ and provide the quantity of fraud, $\mathrm{Q}^{*}$. Equilibrium price and quantity are shown in Graph 1.

The equilibrium price, $\mathrm{P}^{*}$, is the amount the accountant expects to receive from the CEO. The accountant speculates as to how much the fraud means to the CEO (perceives his demand curve), sets MR = MC and charges the maximum price (s)he thinks (s)he can get. The accountant asks for some combination of cash out of pocket from the $\mathrm{CEO}$, a raise and/or promotion, and the accountant has the expectation of greater wealth from stock appreciation. The accountant demands the price, $\mathrm{P}^{*}$; the $\mathrm{CEO}$ who can either reject or agree to the terms.

Consider what happens if the CEO accepts the terms of the offer, the payoff takes place and the transaction is completed. The important question addressed here is the following: why does the CEO accept the terms of the contract? In the standard monopoly model, if the CEO accepts the conditions set by the accountant, (s)he will receive a lower quantity of fraud and will pay a higher price for the fraud than (s)he would prefer. At this point, the CEO's motivation to commit fraud is not clear. The CEO has little apparent personal benefit and will incur a high cost if caught.

The accountant's motivation is clear. (S)he receives a price greater than the marginal cost of the fraud $\left(\mathrm{P}^{*}>\right.$ $\mathrm{MC}$ ) and is thus compensated for the services/risks. The motive for the CEO's participation is less clear.

The CEO accepts the contract because of the ability to extract a better deal for the fraud than the terms offered by the accountant. The CEO manipulates the information and hides the true value of the fraud. In this manner, we assert, the CEO can extract a higher level of fraud at lower cost. The CEO signals his(her) (perceived) NMB by accepting the offer made by the accountant. Once (s)he accepts the offer, the accountant infers the CEO's demand and that the CEO's $\mathrm{NMB}=\mathrm{P}^{*}$. However, the CEO actually receives a lower NMB for $\mathrm{Q}^{*}$ than the accountant believes. Graph 2 shows the CEO's actual demand curve to the left of the perceived demand curve. The difference between point X and point B in Graph 2 is the difference between the CEO's perceived and actual NMB.

\footnotetext{
1 "Since profit is the difference between total revenue and total cost, what happens to profit in response to a change in output is determined by marginal revenue (MR), the change in total revenue associated with a change in quantity, and marginal cost (MC), the change in total cost associated with a change in quantity" (Colander, 2005). A firm will maximize total profits by producing where MR $=$ MC.
} 


\section{Graph 1: Standard Monopoly}

Model

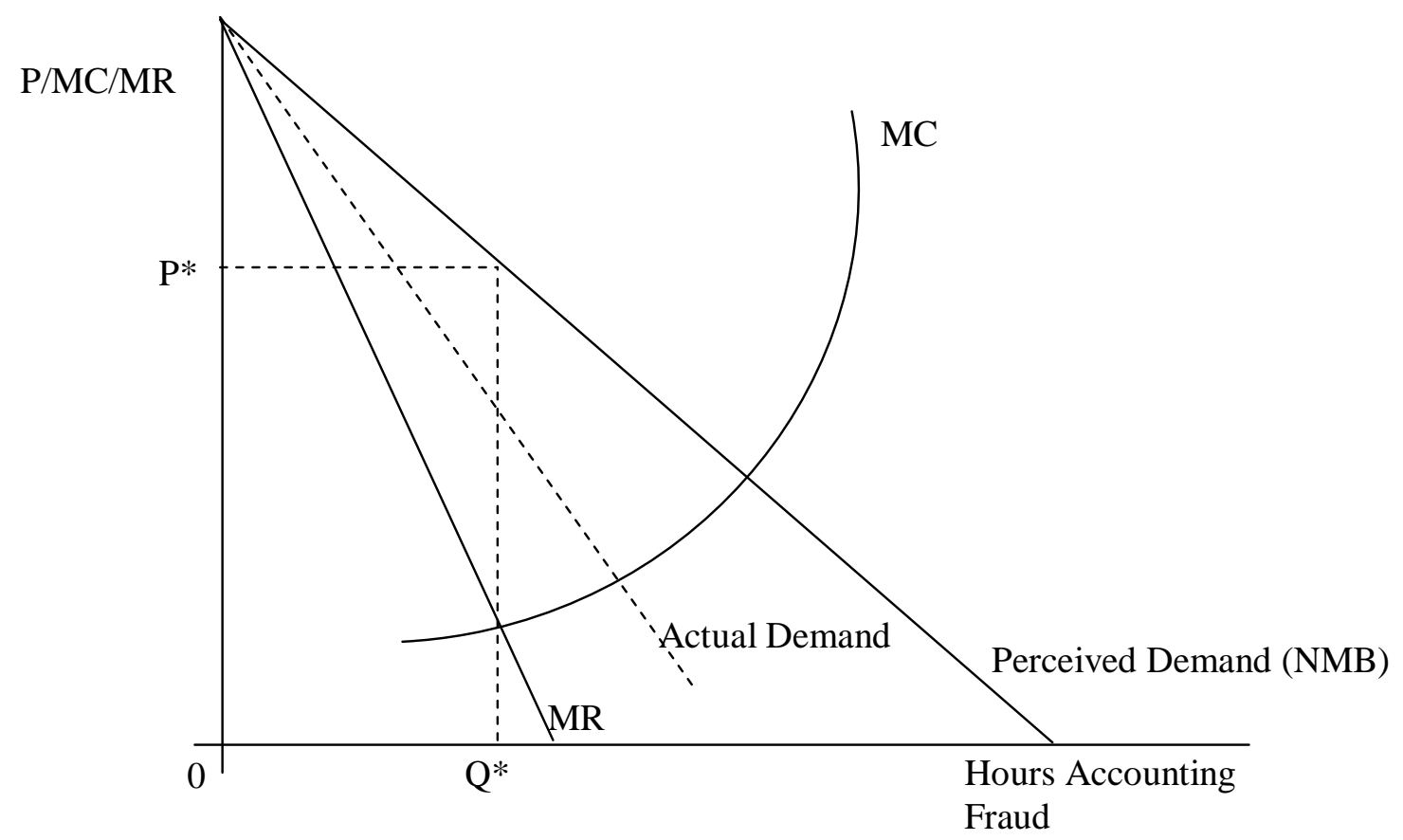

Why does the CEO let the accountant believe that his/her NMB is equal to $\mathrm{P} *$ ? And why does the CEO accept the price $\mathrm{P}^{*}$ if the true value of his $\mathrm{NMB}$ at $\mathrm{Q}^{*}$ is less than $\mathrm{P}^{*}$ (at $\mathrm{Pa}$ )? The CEO can agree to pay $\mathrm{P}^{*}$ to the accountant because his/her status in the company gives him/her the power to act on behalf of the company. The CEO agrees to pay $\mathrm{P}^{*}$ because much of $\mathrm{P}^{*}$ is paid for by the company! For example, giving the accountant a raise and /or promotion, the CEO engages in theft from the company. The raise and/or promotion is based on corruption rather than meritorious performance. By using his/her power, the CEO gets a higher level of fraud output (at $\mathrm{Q}^{*}$ ). If the accountant knew the actual NMB, output would fall from $\mathrm{Q}^{*}$ to $\mathrm{Q} \mathrm{a}^{*}$.

When the CEO withholds from the accountant that his NMB of $\mathrm{Q}^{*}$ is actually more than it really is, the accountant becomes willing to provide more fraud. In this way, the $\mathrm{CEO}$ assures that the accountant will be willing to provide $\mathrm{Q}^{*}$ of fraud rather than $\mathrm{Q} \mathrm{a}^{*}$ of fraud.

In Graph 2 the amount $\mathrm{P}^{*}-\mathrm{Pa}$ is the share of the cost of the fraud that the CEO essentially steals from the firm. In other words, it is the consumer surplus to the CEO. ${ }^{2}$ However, the CEO does not benefit from the entire surplus. (She)he suffers a loss because the actual net marginal benefit at $\mathrm{Q}^{*}$ (point $\mathrm{B}$ ) is less than the net marginal benefit paid. This loss is represented by the triangle YXB. The surplus should be based on the CEO's actual NMB curve in Graph 2. The total surplus is reduced by the amount of YXB; total surplus falls from PaP*XB to PaP*YB.

\footnotetext{
${ }^{2}$ Consumer surplus is the difference between the price the consumer actually pays and the price she would be willing to pay. In this case it is the difference between the price the CEO appears to pay and the price he actually pays.
} 


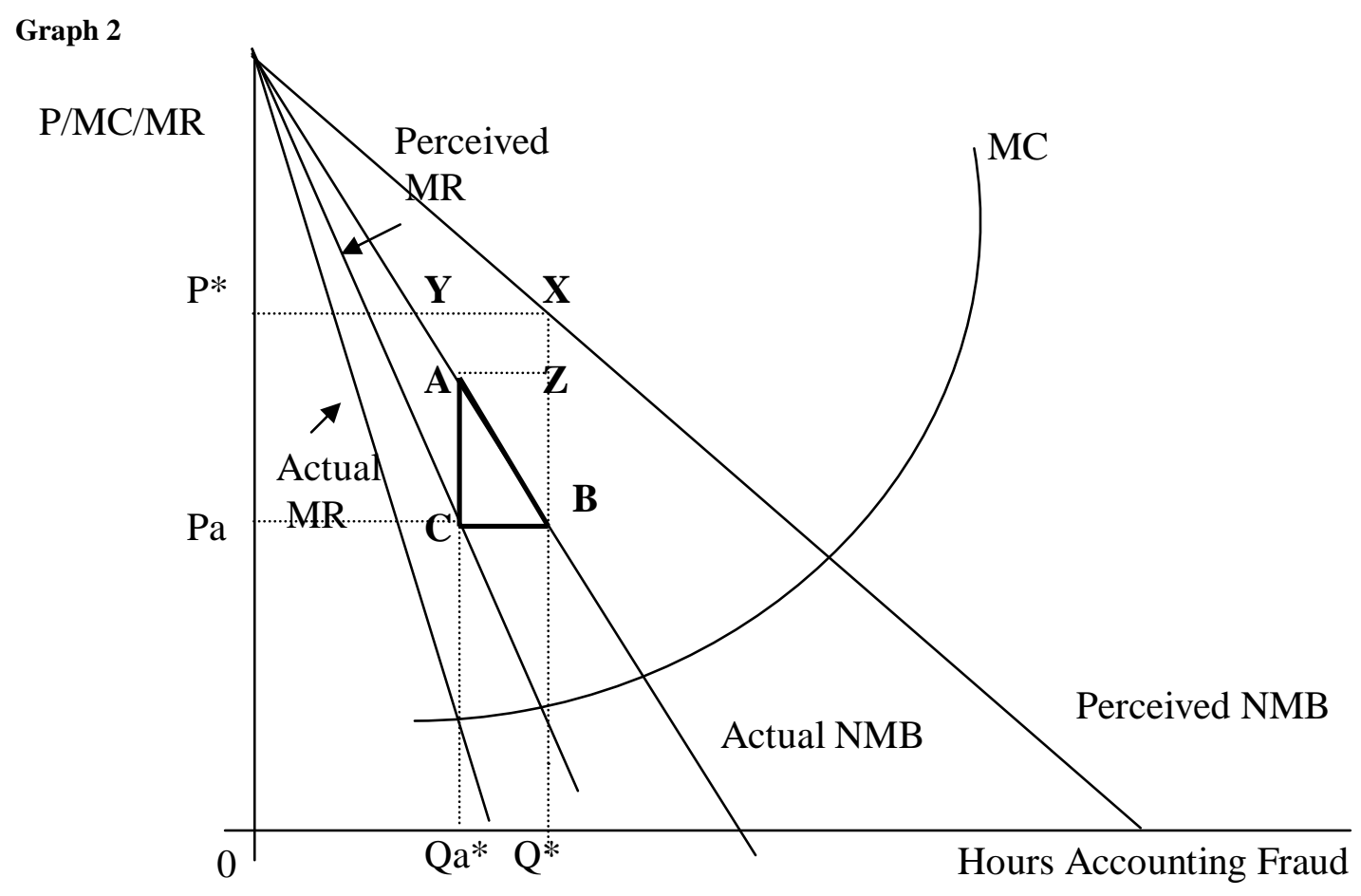

The CEO incurs a lower level of cost when engaging in fraud than (s)he would under the standard monopoly outcome. In Graph 2, the triangle $\mathrm{ABC}$ represents the information rent or surplus the CEO extracts from the accountant. If the accountant knew the actual $\mathrm{NMB}$ curve, output would drop from $\mathrm{PbB}$ to $\mathrm{PbC}$ and the price would increase by $\mathrm{CA}$. Triangle $\mathrm{ABC}$ represents the gain to the $\mathrm{CEO}$ in terms of a greater output.

Finally, consider the net surplus the CEO receives. The total surplus from the information rent is the area $\mathrm{ABC}$ in Graph 2. This surplus of $\mathrm{ABC}$ can be added to the loss in welfare incurred by the CEO due to monopoly pricing (represented by the area of YXB). Thus, subtracting the surplus from the loss, there is a reduction in consumer loss from YXB to AYXZ. By stealing from the firm and hiding the truth about his/her own preferences, the CEO is able to extract a sizable surplus. However, (s)he does still suffer a loss associated with having a lower marginal benefit.

\section{RECENT EXAMPLES}

This model demonstrates an economic motive for a CEO to engage in fraud. It supports the following conclusions: (1) the CEO is able to shift much of the cost of committing accounting fraud to the company, but (2) if caught, the $\mathrm{CEO}$ has the risk of incurring a higher penalty than the subordinate in the accounting fraud.

In the table below, information on recent accounting scandals is summarized. 


\begin{tabular}{|c|c|c|c|c|}
\hline Company & Name & Former Position & Sentence & Source \\
\hline \multirow[t]{4}{*}{ Enron } & Kenneth Lay & Chairman & Still on trial & WSJ 8/12/05 \\
\hline & Jeffrey Skilling & President & Still on trial & WSJ 8/12/05 \\
\hline & Andrew Fastow & $\mathrm{CFO}$ & 10 years & WSJ 7/28/05 \\
\hline & Richard Causey & Accountant & 7 years $\$ 1.25$ million & WSJ $12 / 20 / 05$ \\
\hline \multirow[t]{3}{*}{ WorldCom } & Bernie Ebbers & $\mathrm{CEO}$ & 25 years & WSJ 12/9/05 \\
\hline & Scott Sullivan & $\mathrm{CFO}$ & 5 years & WSJ $12 / 9 / 05$ \\
\hline & Betty Vinson & Accountant & 5 months & WSJ 8/8/05 \\
\hline \multirow[t]{2}{*}{ Tyco } & Dennis Kozlowski & $\mathrm{CEO}$ & $81 / 3-25$ years & WSJ 9/21/05 \\
\hline & Mark Swartz & $\mathrm{CFO}$ & $81 / 3-25$ years & WSJ 9/21/05 \\
\hline \multirow[t]{4}{*}{ HealthSouth } & Richard Scrushy & $\mathrm{CEO}$ & Not guilty & WSJ 6/30/05 \\
\hline & William Owens & Finance chief & 5 years & $C T 12 / 10 / 05$ \\
\hline & Weston Smith & $\mathrm{CFO}$ & $21 / 4$ years & WSJ $12 / 10 / 05$ \\
\hline & Jason Brown & VP of Finance & 1 year & $W P 12 / 23 / 05$ \\
\hline \multirow[t]{3}{*}{ Adelphia } & John Rigas & CEO & 15 years & WSJ $11 / 25 / 05$ \\
\hline & Timothy Rigas & $\mathrm{CFO}$ & 20 years & WSJ 11/25/05 \\
\hline & Michael Mulcahey & Assistant Treasurer & Not guilty & WSJ 7/12/04 \\
\hline
\end{tabular}

\section{Enron}

Richard Causey, the accountant for Enron, pled guilty to a single felony charge of securities fraud and faces a seven-year sentence and a $\$ 1.25$ million fine. His sentence could be reduced by as much as two years (Romero and Bajaj 2005), depending on his cooperation in the prosecution of Lay and Skilling. As the model predicts, the accountant faces a lesser sentence (lower cost) than the CEOs.

In addition to the deal with Causey, prosecutors have reached a plea agreement with Andrew S. Fastow, the former chief financial officer of Enron. Fastow faces ten years in prison.

It suggests that there is no limit to the number of insiders they are willing to bring on board to try to ensure a conviction of Mr. Lay and Mr. Skilling, by far the most prominent figures involved with Enron's collapse. (Romero and Bajaj 2005 C4)

Note that the "prominence" of Lay and Skilling seems to increase the motivation of prosecutors to convict these high-level executives.

\section{WorldCom}

A similar situation occurred with WorldCom. Bernie Ebbers, the founder and former CEO, has been sentenced to twenty-five years for his part in the accounting scandal dubbed "the largest corporate fraud in history." (Quinn 2005) Scott Sullivan, the chief financial officer of WorldCom, pled guilty to three Securities and Exchange Commission (SEC) violations and struck a deal with federal prosecutors in exchange for building a case against Ebbers (Perilloux 2004). Sullivan and four other executives admitted all charges and turned on Ebbers (Quinn 2005). The length of the sentence received correlates perfectly with the level in the company's organizational hierarchy; i.e., the higher the rank, the longer the sentence.

\section{Tyco}

In the Tyco scandal, the CEO (Kozlowski) and the CFO (Swartz) appear to have been viewed as a team. They were tried together with the same charges brought against each of them. They were both sentenced to $81 / 3$ to 25 years. In this case, no distinction appears to have been made between the rank of the CEO and the CFO. 


\section{HealthSouth}

The acquittal of Richard Scrushy was due to a number of factors (Terhune and Morse 2005). For one thing, Mr. Scrushy never testified, so prosecutors could not attack his credibility. Also, Richard Scrushy was tried in the city "where he had built one of Birmingham's most successful enterprises and contributed lavishly to local causes." (Terhune and Morse, 2005). And finally, Scrushy's defense team was successful in persuading the jury that he lacked a motive to commit the fraud because he was already wealthy.

Concerning the other three executives identified in the table above, it is difficult to identify the differences in rank and responsibility based on their titles reported in the press. Owens is the finance chief, Smith is the chief financial officer, and Brown is the vice-president of finance. However, the defense team of Mr. Scrushy "depicted Mr. Owens as the accounting fraud's mastermind" (Terhune 2005), thereby most likely contributing to the stiffer sentence given to Owens.

\section{Adelphia}

The model in this paper would suggest that the CEO should receive a higher sentence than the CFO, which for Adelphia is definitely not the case. Perhaps the best explanation of the "reversal" from expectations in the Rigas's cases is the age difference. John Rigas, the founder and CEO of Adelphia, is 80 years old where as his son, Timothy is 49. The fifteen-year sentence for John Rigas is effectively a life sentence (Searcey and Yuan 2005).

\section{CONCLUSION}

This model rests on four very strong assumptions. First, we assume the CEO has more to lose from the accounting fraud than the accountant. Second, we assume that the CEO is not motivated as much by personal financial gain. Third, we assume that the CEO can hide the true net marginal benefit from the accountant - that information is imperfect. Fourth, we assume the CEO has considerable influence within the company.

The model here explains why Ebbers and Lay, and others like them, might choose to engage in accounting fraud. In spite of the possibility of a significant loss if caught, it is relatively less costly to engage in fraud than might be apparent, given the ability to pass on some of the cost to the company.

\section{REFERENCES}

1. Beasley, Mark S., Jospeh V. Carcello, and Dana R. Hermanson. 2001. Financial Reporting Fraud: Could It Happen to You? The Journal of Corporate Accounting and Finance (May/Jun 2001):3-9.

2. Colander, David. 2005. What Economists Teach and What Economists Do. Journal of Economic Education (Summer 2005):249-261.

3. Eichenwald, Kurt. In Enron Case, a Guilty Plea but No Certainties. New York Times. December 29, 2005. $\mathrm{A} 1$ and $\mathrm{C} 4$.

4. KPMG Forensic Fraud Survey 2003. Published by KPMG International in the USA.

5. Nichols, Bruce. 2005. Enron plea may boost prosecution. The Dallas Morning News. December 29, 2005. p. 1.

6. Perilloux, Gary. 2004. Booneville, Miss.: Investigator Works on Defense Team for Former WorldCom CFO. Knight Ridder Tribune Business News. Washington. April 4, 2004. p.1

7. PwC Global Economic Crime Survey 2003. Published by PricewaterhouseCoopers International.

8. Quinn, James. 2005. Ebbers jailed for 25 years over world's biggest fraud. Knight Ridder Tribune Business News. Washington. July 14, 2005. p. 1.

9. Romero, Simon and Vikas Bajaj. Enron's Top Accountant Will Help Prosecutors. New York Times. December 29, 2005. C1 and C4.

10. Shleifer, Andrei and Robert W. Vishny. 1993. Corruption. Quarterly Journal of Economics, (August 1993):599-618. . 
11. Searcey, Dionne and Li Yuan. Adelphia's John Rigas Gets 15 Years. Wall Street Journal. June 21, 2005. p. A3.

12. Terhune, Chad. Should Cooperation Count - Even if It Failed? Wall Street Journal December 9, 2005. p. C1.

13. Terhune, Chad and Dan Morse. Why Scrushy Won His Trial and Ebbers Lost. Wall Street Journal June 30, 2005. p. C1.

\section{NOTES}

